\title{
The effect of cultivation conditions on the growing processes of grape plants in vitro
}

\author{
Irina Pavlova ${ }^{*}$, E. Luschay, M. Kosyuk, A. Abdurashitova, and Viktor Klimenko
}

Federal State Budget Scientific Institution All-Russian National Research Institute of Viticulture and Winemaking Magarach of the Russian Academy of Sciences, Laboratory of Genetics, Biotechnologies of Selection and Propagation of Grapes, 31 Kirova str., 298600 Yalta, Republic of Crimea, Russia

\begin{abstract}
One of alternative ways to maintain valuable genetic material is to develop optimal conditions for cultivation in an in vitro system. The goal was to evaluate the condition of plants based on changes in the shoot length indicator in order to explore the maintaining mode of the collection. We took the experimental samples from the "Vegetating collection of plants in vitro of promising varieties and clones of grapes": 13 local Crimean varieties and 9 varieties of the Institute Magarach selection. Plant containing culture bottles were in the cold storage without internal lighting at $10-12^{\circ} \mathrm{C}$ for 6 months. The cultivation findings demonstrated that grape varieties differed in viability and intensity of morphogenesis. Moreover, after storage, they had a high regenerating ability of the buds.
\end{abstract}

\section{Introduction}

One of alternative ways to maintain valuable genetic material is to develop optimal conditions for cultivation in an in vitro system [1-5]. The preservation of viable samples in the form of vegetating collection in vitro gives the opportunity to maintain samples of viable grape plants of promising varieties and clones in sterile environment. When the storage mode is optimal, the collection takes up little space, requires minimal concentrations of mineral substances and rare replantation of plant samples [5-8]. To preserve, improve and further mass reproduce, a "Vegetating collection of plants in vitro of promising varieties and clones of grapes" has been created at the Institute Magarach [9]. The collection includes varieties, hybrid forms of the Institute Magarach selection, rootstock varieties, as well as clones of wine grapes. The collection is supported in increased growth mode and in a true dormancy without the use of osmotic adjustment agents and retardants. Today it has more than 100 samples.

The process modes have been developed to preserve the plants of vegetating collection without additional replantation for one year in two cultivation modes: in the light and in the dark [10]. The optimization activities for the maintenance of the collection are in progress.

For defining the optimal characteristics of the main cultivation factors affecting the morphogenesis of plants in the in vitro system, it is reasonable to trace changes in growing processes in a long-time interval. Our paper aims to evaluate the condition of plants on the

*Corresponding author: pavlovairina1965@gmail.com 
basis of changes in the shoot length indicator in order to explore the maintaining mode of the collection.

\section{Materials and methods}

The studies were conducted in the Laboratory of Genetics, Biotechnologies of Selection and Propagation of Grapes. The samples for the research were plants in vitro of 13 local Crimean grape varieties: 'Alburla', 'Kokur Krasnyi', 'Kanagyn Izium', 'Misgiuli Kara', 'Polkovnik Izium', 'Soldaiya', 'Solnechnaya Dolina 31a', 'Solnechnaya Dolina 65', 'Solnechnaya Dolina 58', 'Shira Izium', 'Khalil Izium' and 9 varieties of Institute Magarach selection: 'Rubynovyi Magaracha', 'Granatovyi Magaracha', 'Antei Magarachskiy', 'Aurora Magaracha', 'Yaltinskiy Bessemyannyi', 'Krymskaya Zhemchuzhina', 'Dzhalita', 'Akademik Avidzba', and 'Spartanets Magaracha'. The samples were taken from "Vegetating collection of plants in vitro of promising varieties and clones of grapes". The plant samples were propagated by micrografting. They were cultured for four weeks on a hormone-free PG medium, at a 16-hour photoperiod; the temperature was $+25-27^{\circ} \mathrm{C}$ [11]. Afterwards, plant containing culture bottles were in the cold storage without internal lighting at $10-12^{\circ} \mathrm{C}$ for 6 months. We monthly recorded changes in the plant shoot length indicator.

To identify regenerating ability of the bud, two-eyed sprouting explants of shoots were planted in a medium MS with 6-benzylaminopurine (BAP) at a concentration of $0.5 \mathrm{mg} / \mathrm{l}$ [12]. They were cultivated for a month in a light room at $+27^{\circ} \mathrm{C}$ and a 16 -hour photoperiod.

The findings were assessed basing on changes in the shoot length indicator.

\section{Results and discussion}

It is known that the main factors affecting plant morphogenesis are lighting, temperature, photoperiod, and cultivation environment. Decreasing the temperature in extremely low light should have resulted in deceleration of growing processes. The growing processes have partially been decelerated. Nevertheless, they have not stopped. Among the plants of the studied varieties, the pattern was mixed (table 1). After plants were transferred to cultivation conditions at $+10-12^{\circ} \mathrm{C}$, without additional lighting, shoot growth in all the studied varieties has practically stopped. The plants were under stress. Following five months of cultivation, the pttern has fundamentally changed (fig. 1).

Under such conditions some varieties were viable for five months. In the sixth month of cultivation, leave decay and branch necrosis of plants of the varieties 'Shira Izium', 'Khalil Izium' and 'Kokur Krasnyi' had begun.

In the remaining plants of other local varieties, both the suspension of morphogenesis and a certain shoot growth were observed (fig. 2). According to the rate of shoot growth, the experimental samples were divided into three groups, characterized by a lack of growth, a weak growth increase, and a significant growth increase.

Table 1. The shoot growth dynamics of plants in vitro of local Crimean grape varieties

\begin{tabular}{|l|c|c|c|c|c|c|}
\hline \multirow{2}{*}{ Variety } & \multicolumn{5}{|c|}{ Average shoot length, cm } & \multirow{2}{*}{$\begin{array}{c}\text { Growth } \\
\text { gain, \% }\end{array}$} \\
\cline { 2 - 6 } & January & February & March & May & June & 3.03 \\
\hline 'Alburla' & 3.30 & 3.40 & 3.40 & 3.40 & 3.40 & 3.40 \\
\hline 'Kokur Krasnyi' & 2.10 & 2.16 & 2.20 & 2.38 & 2.45 & 16.67 \\
\hline 'Kanagyn Izium' & 2.30 & 2.30 & 2.30 & 2.30 & 2.30 & 0.00 \\
\hline 'Misgiuli Kara' & 3.10 & 3.10 & 3.10 & 3.10 & 3.10 & 0.00 \\
\hline 'Polkovnik Izium' & 2.65 & 2.65 & 2.70 & 2.70 & 2.70 & 1.89 \\
\hline 'Soldaiya' & 3.20 & 3.20 & 3.30 & 3.30 & 6.30 & 96.88 \\
\hline
\end{tabular}




\begin{tabular}{|l|c|c|c|c|c|c|}
\hline $\begin{array}{l}\text { 'Solnechnaya } \\
\text { Dolina 31a' }\end{array}$ & 1.80 & 1.80 & 1.80 & 1.80 & 1.80 & 0.00 \\
\hline $\begin{array}{l}\text { 'Solnechnaya } \\
\text { Dolina 58' }\end{array}$ & 3.60 & 3.60 & 3.60 & 3.60 & 3.60 & 0.00 \\
\hline $\begin{array}{l}\text { 'Solnechnaya } \\
\text { Dolina 65' }\end{array}$ & 4.20 & 4.30 & 4.30 & 4.30 & 5.50 & 30.95 \\
\hline 'Sary Pandas' & 3.50 & 4.30 & 4.70 & 4.70 & 4.70 & 34.29 \\
\hline LSD 05 & \multicolumn{7}{|c|}{13.42} & & \\
\hline LSD \% & \multicolumn{7}{|c|}{13.13} \\
\hline
\end{tabular}

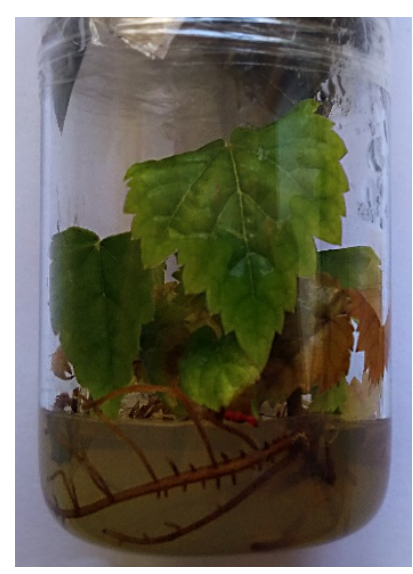

$\mathbf{a}$

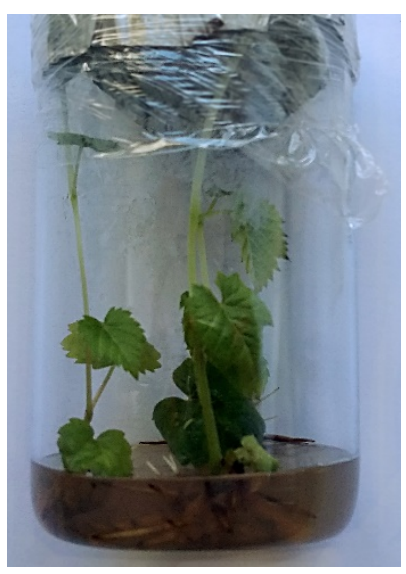

b

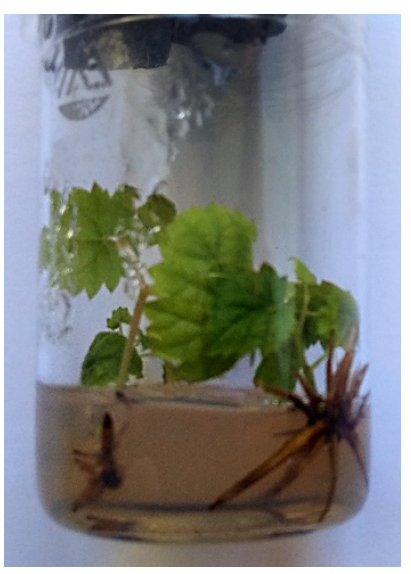

c

Fig. 1. The plants of local Crimean grape varieties after cold storage cultivation at $12^{\circ} \mathrm{C}$ without lighting, 2020: a - 'Kanagyn Izium', b - 'Soldaiya', c - 'Solnechnaya Dolina 31a'.

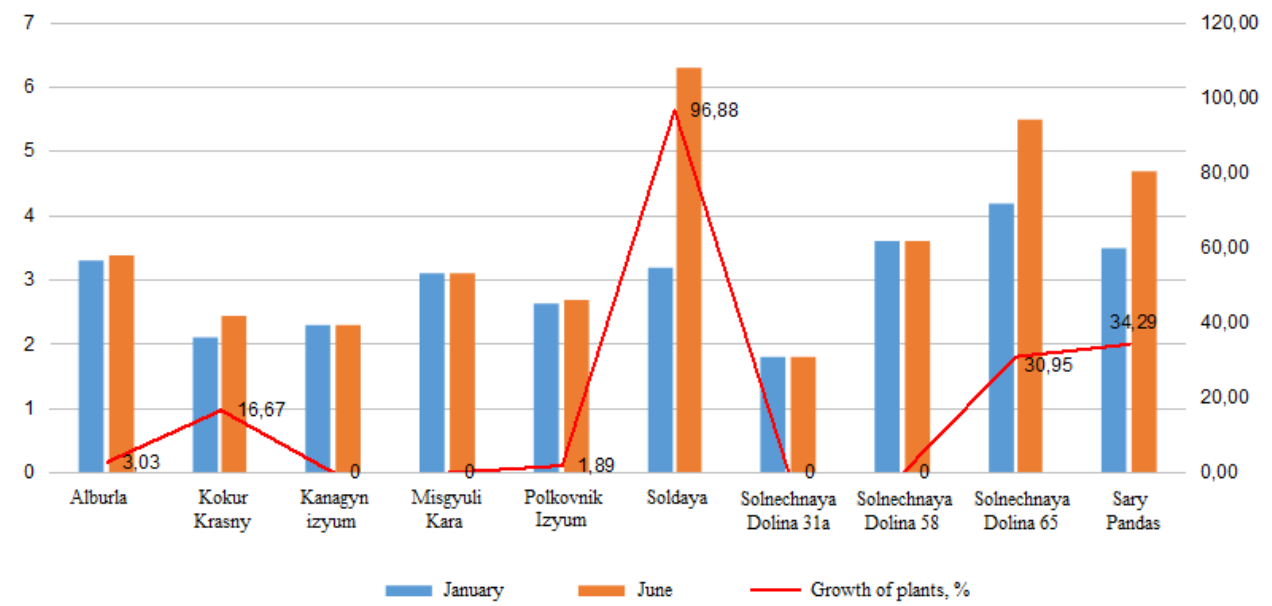

Fig. 2. The change in the shoot length of plants in vitro of local Crimean varieties after 6 months of cultivation

The plants of the Institute Magarach varieties were more viable. They possessed the ability to morphogenesis under severe cultivation conditions (fig. 3). 


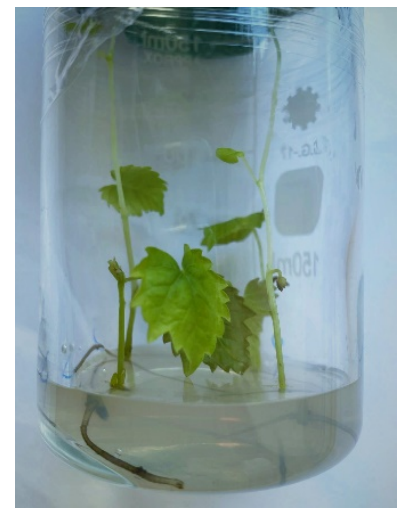

a

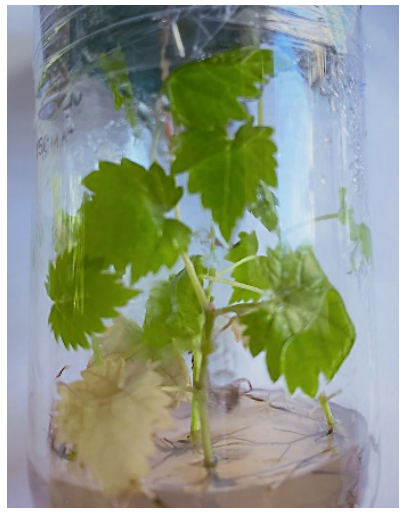

b

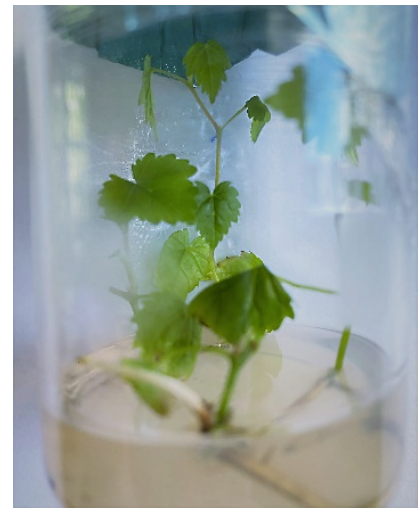

c

Fig. 3. The plants of grape varieties selected in the Institute Magarach after cold storage cultivation at $12^{\circ} \mathrm{C}$ without lighting: a - 'Aurora Magaracha', b - 'Rubinovyi Magaracha', c - 'Yaltinskiy Bessemyannyi'.

The exception was the plants of 'Antei Magarachskiy' variety. Morphogenesis has practically stopped in them (table. 2). According to the change in the number of internodes, we have observed mainly the apical growth. The initial length of shoots by varieties ranged from $1.34 \mathrm{~cm}$ ('Spartanets Magaracha') to $3.58 \mathrm{~cm}$ ('Granatovyi Magaracha'), which did not further influence the morphogenesis. The plants were marked by a weak, medium, and significant growth of shoots, depending on the variety.

Table 2. Indicators of change in the shoot length of plants in vitro of grape varieties selected in the Institute Magarach

\begin{tabular}{|c|c|c|c|c|c|c|}
\hline \multirow[t]{2}{*}{ Variety } & \multicolumn{2}{|c|}{$\begin{array}{c}\text { Average shoot } \\
\text { length, } \mathrm{cm}\end{array}$} & \multirow[t]{2}{*}{$\begin{array}{l}\text { Growth } \\
\text { gain, \% }\end{array}$} & \multicolumn{2}{|c|}{$\begin{array}{l}\text { Average number of } \\
\text { internodes, pcs. }\end{array}$} & \multirow[t]{2}{*}{$\begin{array}{l}\% \text {, change } \\
\text { in } \\
\text { internodes }\end{array}$} \\
\hline & January & June & & January & June & \\
\hline 'Rubinovyi Magaracha' & 3,48 & 5,69 & 63,58 & 2,45 & 4,58 & 86,94 \\
\hline 'Yaltinskiy Bessemyannyi' & 2,49 & 3,12 & 25,17 & 2,18 & 2,78 & 27,52 \\
\hline 'Granatovyi Magaracha' & 3,58 & 4,05 & 13,13 & 3,40 & 4,90 & 44,12 \\
\hline 'Krymskaya Zhemchuzhina' & 4,04 & 6,19 & 53,25 & 3,50 & 4,77 & 36,29 \\
\hline 'Spartanets Magaracha' & 1,34 & 1,72 & 28,36 & 1,60 & 1,80 & 12,50 \\
\hline 'Aurora Magaracha' & 2,25 & 3,58 & 58,89 & 1,25 & 2,25 & 80,00 \\
\hline 'Dzhalita' & 3,19 & 3,63 & 13,64 & 1,90 & 2,75 & 44,74 \\
\hline 'Akademik Avidzba' & 2,46 & 3,09 & 25,46 & 2,40 & 3,58 & 49,17 \\
\hline 'Antei Magarachskiy’ & 2,43 & 2,50 & 3,09 & 2,34 & 2,41 & 2,99 \\
\hline $\operatorname{LSD}_{05}$ & \multicolumn{2}{|c|}{0,60} & & \multicolumn{2}{|c|}{0,49} & \\
\hline LSD $\%$ & \multicolumn{2}{|c|}{18,53} & & \multicolumn{2}{|c|}{17,52} & \\
\hline
\end{tabular}

After six months of cold storage cultivation at $+10-12^{\circ} \mathrm{C}$ without additional lighting, the bud viability of local varieties was tested. In most varieties, the good viability of buds was preserved (fig.4). Some varieties had partial wilting of regenerated shoots. 


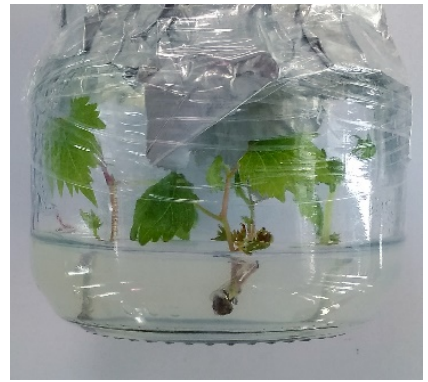

a

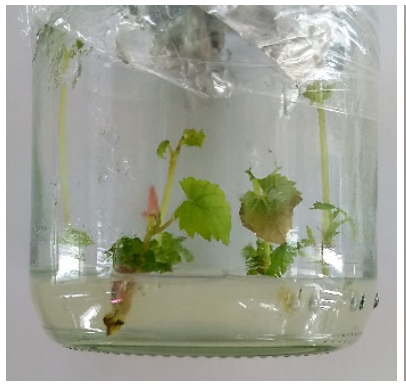

b

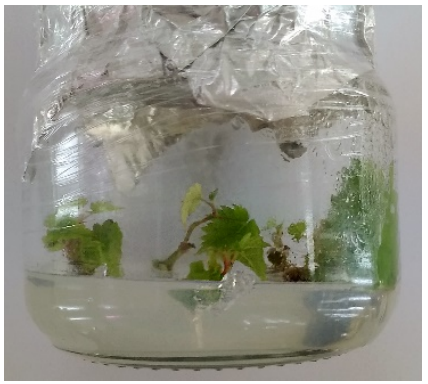

c

Fig. 4. Bud regeneration of local Crimean grape varieties after cold storage cultivation at $12^{\circ} \mathrm{C}$ without lighting, a - 'Kanagyn Izium', b - 'Soldaiya', c - 'Solnechnaya Dolina 31a'

\section{Conclusions}

According to the studies, grape plants are capable to morphogenesis in conditions of low positive temperature and extremely low light. Meanwhile, varietal specificity is distinctly manifested. The viability of plants in these conditions also depends on the variety. The plants of all local varieties survived five months of cultivation without changing the shoot length indicator. Then a critical period began, which divided the varieties into two groups according to the external condition of the plants: viable and non-viable. The main cause of plant death was the decay of leaves and drying of shoots. According to the morphogenesis dynamics, the degree of shoot growth, the experimental samples were separated into three groups characterized by the absence of growth, weak and significant growth.

The Institute Magarach varieties of various origin differed from the local Crimean ones in their capability to morphogenesis under critical cultivation conditions. There was a weak, average, and significant growth of the shoot, depending on the variety.

The cultivation of plants at $+12^{\circ} \mathrm{C}$ without lighting for 6 months revealed that grape varieties differed in viability and intensity of morphogenesis. There was a high regenerative capacity of buds in the majority of the studied samples after storage.

\section{Reference}

1. J.B. Bamberg, M.W. Martin, J. Abad, M.M. Jenderek, J. Tanner, D.J. Donnelly, A M.K. Nassar, R.E. Veilleux, R.G. Novy., In V Cel \& Devel B - Pl, 52, 213-225 (2016) DOI:10.1007/s11627-016-9753-x.

2. I.V. Mitrofanova, N.N. Ivanova, V.A. Brailko, Act Hor, 1298, 167-174 (2020) DOI:10.17660/ActaHortic.2020.1298.24.

3. E.V. Spiridovich, T.I. Fomenko, A.B. Vlasova, O.N. Kozlova, I.F. Voynovskaya, A.N. Yukhimchuk, S.M. Kuzmenkova, O.N. Veselovsky, V.N. Reshetnikov, N of the Nat Ac of Sc of Bel. Ser of Biol Sc, 3, 117-128 (2017)

4. O. Imarhiagbe, J.O. Osazee, R.O. Aiwansoba, O.H. Shittu, Int J of B R, 1, 9-14 (2016)

5. B. Panis, M. Nagel, I., Pl, 9(12), 22 p. (2020). doi:10.3390/plants9121634

6. S. Tehrim, G.M. Sajid, Rom Biot Lett, 16(6), 6781-6789 (2011)

7. C.A. Cruz-Cruz, M.T. Gonzalez-Arnao, F. Engelmann, Res, 2, 73-95 (2013)

8. F. Engelmann, In Vit C Dev. Biol. Plant, 47, 5-16 (2011) 
9. I.A. Pavlova, E.A. Lushchai, A.V. Petukhova, A.S. Abdurashitova, Win Tr, 22(2), 9599 (2020) DOI 10.35547/IM.2020.20.46.002

10. I.A. Pavlova "Vegetative collection of grape plants in vitro, storage conditions". Biotechnology of plant cells in vitro and biotechnology: Abstracts of the XI International Conference, Minsk, 170-171 (2018)

11. V.A. Zlenko, L.P. Troshin, I.V. Kotikov, Vitis, 34, 125-126 (1995)

12. T. Murashige, F. Skoog, Physiol. Plant, 15(13), 473-497 (1962) 